\title{
Production of L-Tryptophan by 5-Fluorotryptophan Resistant Mutants of Bacillus subtilis
}

\author{
Isamu SHIIO, Kenji IsHII and Kenzo YoKozeKI \\ Central Research Laboratories of Ajinomoto Co., Inc., Kawasaki, Japan
}

Received December 23, 1972

\begin{abstract}
The growth of Bacillus subtilis TR-44, a prototrophic transductant from one of inosine producers, was completely inhibited by $200 \mu \mathrm{g} / \mathrm{ml}$ of 5-fluorotryptophan, a tryptophan ana-

1 logue, and the inhibition was reversed by the addition of L-tryptophan.

Several mutants resistant to 5FT* produced L-tryptophan in the growing cultures. The best producer, strain FT-39, which was selected on a medium containing $1500 \mu \mathrm{g} / \mathrm{ml}$ of $5 \mathrm{FT}$, produced $2 \mathrm{~g} /$ liter of L-tryptophan, when cultured in a medium containing $8 \%$ of glucose but without any tryptophan precursors. In this mutant, anthranilate synthetase, a key enzyme of the tryptophan biosynthesis, had increased over 280 -fold, presumably owing to a genetic derepression. From FT-39, mutants resistant to $7000 \mu \mathrm{g} / \mathrm{ml}$ of $5 \mathrm{FT}$ were derived. Among them, strain FF- 25 produced $4 \mathrm{~g} /$ liter of L-tryptophan, twice as much as did the parental strain. Since this strain produced large amount of L-phenylalanine as well as L-tryptophan, the genetic alteration seemed to be involved in some metabolic regulation of common part of the aromatic amino acid biosynthetic pathway.

Further, some auxotrophs derived from these 5FT resistant mutants produced more L-tryptophan than did the parental strains.

Relationships between the accumulation of L-tryptophan and the regulation mechanisms of the L-tryptophan biosynthesis were discussed.
\end{abstract}

Various attempts using tryptophan precursors such as indole and anthranilic acid have been made for the microbial production of L-tryptophan. ${ }^{\sim \sim 5)}$ However, these methods are not advantageous as these precursors are very expensive. On the other hand, the previous study has revealed that 5-methyltryptophan resistant phenylalanine and tyrosine double auxotroph of Brevibacterium flavum, one of glutamate producers, accumulates $2 \mathrm{~g} /$ liter of L-tryptophan in a medium containing $10 \%$ of glucose but without any tryptophan precursors. ${ }^{6}$ However, the yield of L-tryptophan by this mutant was still not so good for the industrial purpose.

Therefore, it was tried to use Bacillus subtilis as the parental strain for further derivation of L-tryptophan producers.

The fact that mutants which produce large amounts of inosine had already been derived

* The abbreviations used through this paper include: 5-fluorotryptophan, 5FT; N-methyl-N'-nitro$\mathrm{N}$-nitrosoguanidine, NG. from Bacillus subtilis ${ }^{7 /}$ suggests that this bacterium may have strong pentose cycle which relates to the biosynthesis of erythrose-4phosphate and 5-phosphoribosyl pyrophosphate, precursors of L-tryptophan. On the other hand, regulation of the aromatic amino acid biosynthesis in Bacillus subtilis has been extensively studied as shown in Fig. 1.8 13) These studies may provide useful suggestions for the derivation of tryptophan producing mutants. The present paper deals with the isolation of 5FT resistant tryptophan producing mutants of Bacillus subtilis, derivation of various auxotrophs from the 5FT resistant strains, cultural conditions for the tryptophan production, and with the relationships between the accumulation of L-tryptophan and the regulation of the aromatic amino acid biosynthesis.

\section{MATERIALS AND METHODS}

Bacterial strains. Bacillus subtilis $\mathrm{TR}-44$, a pro- 


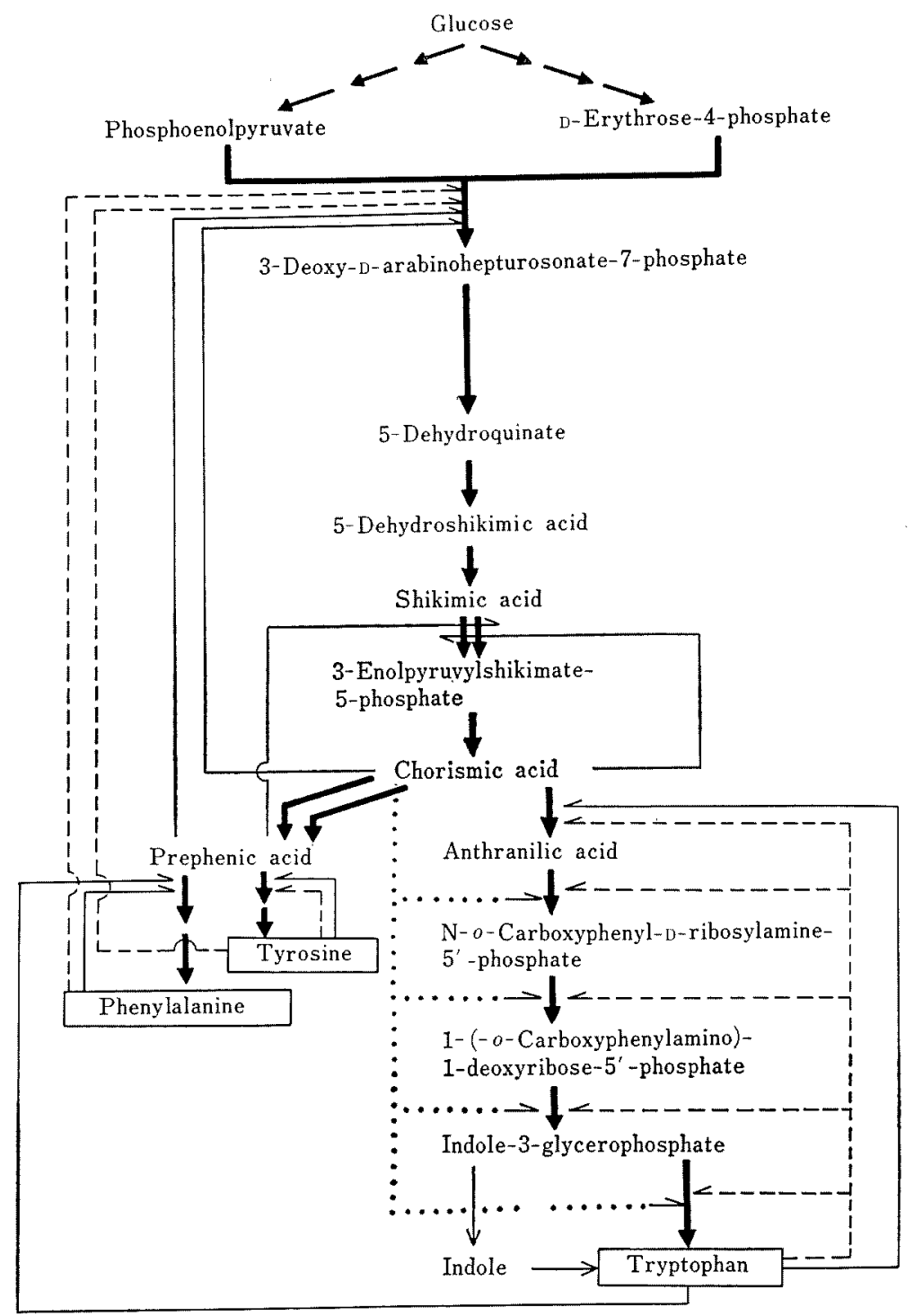

FIG. 1. Summary of Feedback Control in the Biosynthesis of Aromatic Amino Acids of B. subtilis. - feedback inhibition; ---.--, repression; $\cdots$, induction.

totrophic transductant derived from Bacillus subtilis J-No. 2 ( ade $\left.^{-}\right)$, was employed as the starting strain for the derivation of mutants (Table. I).

Phage. SP-10, a generalized transducing phage of Bacillus subtilis, was employed.

Culture media. Medium 1: Polypeptone, $10 \mathrm{~g}$; yeast extract, $10 \mathrm{~g} ; \mathrm{NaCl}, 5 \mathrm{~g}$; and distilled water to bring the total volume to 1 liter; adjusted to $\mathrm{pH} 7.0$. Medium 2: Glucose, $5 \mathrm{~g} ; \mathrm{KH}_{2} \mathrm{PO}_{4}, 8.65 \mathrm{~g} ; \mathrm{KOH}$, $2.18 \mathrm{~g} ;\left(\mathrm{NH}_{4}\right)_{2} \mathrm{SO}_{4}, 1 \mathrm{~g} ; \mathrm{Na}$-citrate, $0.5 \mathrm{~g} ; \mathrm{MgSO}_{4} \cdot 7 \mathrm{H}_{2} \mathrm{O}$ $0.2 \mathrm{~g}$; the amino acid mixture of casein acid hydro- lysate composition except that L-phenylalanine, Ltyrosine, and L-tryptophan* were omitted, $0.2 \mathrm{~g}$; and distilled water to bring the total volume to 1 liter. Medium 3: Meat extract, $14 \mathrm{~g}$; polypeptone, $8 \mathrm{~g}$;

* The mixture was consisted of the following amino acids: L-Glutamic acid, $122.8 \mathrm{mg}$; L-methionine, $31.4 \mathrm{mg}$; L-lysine, $120.0 \mathrm{mg}$; L-serine, $80.0 \mathrm{mg}$, Laspartic acid, $72.8 \mathrm{mg}$; L-cysteine, $0.4 \mathrm{mg}$; L-alanine, $40.0 \mathrm{mg}$; L-histidine, $25.6 \mathrm{mg}$; L-arginine, $41.4 \mathrm{mg}$; L-proline, $130.0 \mathrm{mg}$; L-valine, $84.4 \mathrm{mg}$; L-isoleucine, $64.4 \mathrm{mg}$; L-leucine, $95.6 \mathrm{mg}$; L-threonine, $55.8 \mathrm{mg}$; and glycine, $25.6 \mathrm{mg}$ per $1 \mathrm{~g}$. 
TABLE I. Bacillus subtilis Strains

\begin{tabular}{|c|c|}
\hline Strains & Description \\
\hline $\mathbf{K}$ & Prototroph; wild type. \\
\hline J-No. 2 & $\begin{array}{l}\text { Adenine auxotroph of strain } \mathrm{K} \text {; inosine } \\
\text { producer. }\end{array}$ \\
\hline TR -44 & $\begin{array}{l}\text { Prototroph; transductant derived from } \\
\text { J-No. } 2 \text { with phage SP-10. }\end{array}$ \\
\hline FT -39 & $\begin{array}{l}\text { 5FT resistant mutant derived from } \\
\text { TR-44; tryptophan producer. }\end{array}$ \\
\hline $\mathrm{FF}-25$ & $\begin{array}{l}\text { 5FT resistant mutant derived from } \\
\text { FT-39; tryptophan and phenylalanine } \\
\text { producer. }\end{array}$ \\
\hline TT -4 & Tryptophan auxotroph of TR -44 \\
\hline FP-13 & $\begin{array}{l}\text { Phenylalanine auxotroph of FT-39; } \\
\text { tryptophan producer. }\end{array}$ \\
\hline FA-32, 39 & $\begin{array}{l}\text { Arginine auxotrophs of FT-39; trypto- } \\
\text { phan producers. }\end{array}$ \\
\hline FL-97 & $\begin{array}{l}\text { Lysine auxotroph of FT-39; trypto- } \\
\text { phan producer. }\end{array}$ \\
\hline FFA-3, 39 & $\begin{array}{l}\text { Arginine auxotrophs of FF-25; trypto- } \\
\text { phan producers. }\end{array}$ \\
\hline FFL-5 & $\begin{array}{l}\text { Leucine auxotroph of FF-25, trypto- } \\
\text { phan producer. }\end{array}$ \\
\hline FFL-90 & $\begin{array}{l}\text { Leucine bradytroph of } \mathrm{FF}-25 \text {; trypto- } \\
\text { phan producer. }\end{array}$ \\
\hline FFU-6, 34, 80 & $\begin{array}{l}\text { Purine auxotrophs of } \mathrm{FF}-25 \text {; trypto- } \\
\text { phan producer. }\end{array}$ \\
\hline
\end{tabular}

yeast extract, $4 \mathrm{~g}$; glucose, $1 \mathrm{~g}$; and distilled water to bring the total volume to 1 liter; adjusted to $\mathrm{pH} 7.2$. Medium 4: Glucose, $80 \mathrm{~g} ; \mathrm{NH}_{4} \mathrm{Cl}, 20 \mathrm{~g} ; \mathrm{KCl}, 2 \mathrm{~g}$; $\mathrm{KH}_{2} \mathrm{PO}_{4} 1 \mathrm{~g} ; \mathrm{MgSO}_{4} \cdot 7 \mathrm{H}_{2} \mathrm{O}, 0.4 \mathrm{~g} ; \mathrm{Fe}^{2+}, 2 \mathrm{ppm}$; $\mathrm{Mn}^{2+}, 2 \mathrm{ppm} ; \mathrm{CaCO}_{3}, 25 \mathrm{~g}$; the amino acid mixture, ${ }^{*}$ $2 \mathrm{~g}$; and distilled water to bring the total volume to 1 liter; adjusted to $\mathrm{pH}$ 7.0. Medium 5: Glucose, $80 \mathrm{~g} ; \mathrm{NH}_{4} \mathrm{Cl}, 10 \mathrm{~g} ; \mathrm{KCl}, 2 \mathrm{~g} ; \mathrm{KH}_{2} \mathrm{PO}_{4}, 1 \mathrm{~g} ; \mathrm{MgSO}_{4} \cdot$ $7 \mathrm{H}_{2} \mathrm{O}, 0.4 \mathrm{~g} ; \mathrm{Fe}^{2+}, 2 \mathrm{ppm} ; \mathrm{Mn}^{2+}, 2 \mathrm{ppm} ; \mathrm{CaCO}_{3}$, $25 \mathrm{~g}$; the amino acid mixture, $3 \mathrm{~g}$; and distilled water to bring the total volume to 1 liter; adjusted to $\mathrm{pH} 7.0$. Medium 6: Glucose, $80 \mathrm{~g} ; \mathrm{NH}_{4} \mathrm{Cl}, 10 \mathrm{~g} ; \mathrm{KCl}, 2 \mathrm{~g}$; $\mathrm{KH}_{2} \mathrm{PO}_{4}, 1 \mathrm{~g} ; \mathrm{MgSO}_{4} \cdot 7 \mathrm{H}_{2} \mathrm{O}, 0.4 \mathrm{~g} ; \mathrm{Fe}^{2+}, 2 \mathrm{ppm}$; $\mathrm{Mn}^{2+}, 2 \mathrm{ppm} ; \mathrm{CaCO}_{3}, 25 \mathrm{~g}$; the amino acid mixture, ${ }^{*}$ $4 \mathrm{~g}$; and distilled water to bring the total volume to 1 liter; adjusted to $\mathrm{pH}$ 7.0. $\mathrm{CaCO}_{3}$ was sterilized separately in medium 4,5 , and 6 .

Chemicals. 5-Fluoro-DL-tryptophan, 6-fluoroDL-tryptophan, 4-methyl-DL-tryptophan, 5-methyl-DLtryptophan, 6-methyl-DL-tryptophan, 7-methyl-DLtryptophan, $\alpha$-methyl-DL-tryptophan, 5-methoxy-DLtryptophan, 5-hydroxy-DL-tryptophan, N-acetyl-DLtryptophan, DL-tryptophanhydroxamate, adenine, Lglutamine, and dithiothreitol were purchased from Sigma Corp., EDTA from Wako Junyaku Corp., and NG from Aldrich Chem. Corp. All the amino acids used were the product of Ajinomoto Co., Inc. Chorismic acid was prepared by $\mathrm{Mr}$. R. Miyajima of our laboratories according to the method of Gibson. ${ }^{14}$ )

Culture conditions. For fermentation experiments, a loopful of cells grown on medium 1 agar plates for 1 day at $30^{\circ} \mathrm{C}$ was inoculated into $20 \mathrm{ml}$ of a culture medium distributed in $500 \mathrm{ml}$ flasks, or into $3 \mathrm{ml}$ of medium distributed in test tubes, which had been sterilized at $115^{\circ} \mathrm{C}$ for $10 \mathrm{~min}$. After cultivation on a shaker at $30^{\circ} \mathrm{C}$, growth, $\mathrm{pH}$, and L-tryptophan accumulated were determined. Growth was represented as optical density at $562 \mathrm{~m} \mu$ after 26-fold dilution with $0.1 \mathrm{~N} \mathrm{HCl}$. LuTryptophan accumulated in the culture broth was detected by paper chromatography with solvent system of butanol:acetic acid: water (4:1:2 by volume) using ninhydrin solution and Ehrlich solution ( $p$-dimethylaminobenzaldehyde $1 \mathrm{~g}$, acetone $90 \mathrm{ml}$, conc. $\mathrm{HCl} 10 \mathrm{ml}$ ) as the color-producing reagents. Quantitative determination of Ltryptophan was conducted by microbioassay with Leuconostoc mesenteroides P-60.

Isolation of $5 F T$ resistant mutants. Cells of late logarithmic phase grown in $5 \mathrm{ml}$ of medium 1 were washed with $0.05 \mathrm{M} \mathrm{Na} \mathrm{HPO}_{4}-\mathrm{KH}_{2} \mathrm{PO}_{4}$ buffer (pH 7.0 ), and resuspended in an equal volume of the same buffer containing $750 \mu \mathrm{g} / \mathrm{ml}$ of $\mathrm{NG}$. After standing for $20 \sim 30 \mathrm{~min}$ in an ice bath, cells were washed twice with the buffer.

The number of viable cells were reduced to $1 \sim 10 \%$ by NG treatment. After suitable dilution, one tenth $\mathrm{ml}$ of NG treated cell suspensions was spread on medium 3 agar plates containing various concentrations of $5 F T$, and cultured for 2 days at $37^{\circ} \mathrm{C}$. 5FT resistant colonies appeared were tested for the tryptophan production.

Isolation of various auxotrophs. One tenth $\mathrm{ml}$ of cell suspensions which had been treated by NG washed and diluted as mentioned above was spread and cultured on medium 1 agar plates. Then, among colonies thus appeared, the ones which did not grow on medium 2 without the amino acids except for Lthreonine, L-isoleucine, L-methionine, and L-glutamic acid were isolated by the replica method, and the auxotrophy was determined by the auxanographic techniques.

Enzyme assay. Anthranilate synthetase was assayed as follows. ${ }^{15}$. The cells grown in $20 \mathrm{ml}$ of medium 6 for $24 \mathrm{hr}$ were suspended in a $0.05 \mathrm{M}$ potassium phosphate buffer ( $\mathrm{pH} 7.0$ ) containing $1 \mathrm{~mm}$ EDTA, $5 \mathrm{mM}$ dithiothreitol, and $0.5 \mathrm{M} \mathrm{KCl}$, and sonically distrupted for $10 \mathrm{~min}$ at $10 \mathrm{kc}$. After centrifugation at $15,000 \mathrm{rpm}$ for $20 \mathrm{~min}$, the supernatant was used as the enzyme extract. The reaction mixture contained $50 \mu$ moles of potassium phosphate buffer 
(pH 7.0), $10 \mu$ moles of $\mathrm{MgSO}_{4}, 20 \mu$ moles of L-glutamine, and $0.2 \mu$ moles of chorismic acid in a final volume of $1 \mathrm{ml}$. The reaction was initiated by the addition of the enzyme extract to the reaction mixture and carried out for $30 \mathrm{~min}$ at $30^{\circ} \mathrm{C}$. As soon as the reaction was stopped by the addition of $4 \mathrm{ml}$ of cold water, the activity was determined with a Hitachi spectrophotofluorometer 203 by observing increase of fluorescence at excitation wave length of $320 \mathrm{~m} \mu$, and emission wave length of $395 \mathrm{~m} \mu$, and comparing the fluorescence to a standard curve for authentic anthranilate. Protein was determined by the method of Lowry et $a{ }^{16}{ }^{16}$

Transduction procedure. $1 \mathrm{ml}$ of culture broth $\left(10^{8} \sim 10^{9}\right.$ cells $\left./ \mathrm{ml}\right)$ of the late logarismic phase grown in $5 \mathrm{ml}$ of medium 3 was mixed with $1 \mathrm{ml}$ of phage SP-10 $\left(10^{8} \sim 10^{9}\right.$ plaque forming units $\left./ \mathrm{ml}\right)$. After $30 \mathrm{~min}$, the cells were washed and resuspended with the buffer. One tenth $\mathrm{ml}$ of the cells was spread on medium 2 agar plates, and cultured for 2 days at $37^{\circ} \mathrm{C}$. Transductants appeared were isolated.

Phage sensitivity test. The cells were spread on medium 1 agar plates, and phage SP-10 was added dropwise to this medium.

After incubation for 1 day at $37^{\circ} \mathrm{C}$, the lytic response was observed (drop test).

Lysogenicity test. A loopful of cells was inoculated into $5 \mathrm{ml}$ of medium 3 and cultured for $16 \mathrm{hr}$ at $37^{\circ} \mathrm{C}$. The presence of the phage in the culture filtrate was assayed by the drop test.

\section{RESULTS}

Derivation of ade ${ }^{+}$transductants from inosine producing bacterium, Bacillus subtilis $J_{-}$ No. 2

Bacillus subtilis $\mathrm{K}$ (final concentration, $1.5 \times 10^{7}$ cells $/ \mathrm{ml}$ ) and phage SP-10 (final concentration, $5.0 \times 10^{7} \quad$ P.F.U $/ \mathrm{ml}$ ) was inoculated into $5 \mathrm{ml}$ of medium 3. Growth of the cells infected with phage SP-10 reached the maximum after $4.5 \mathrm{hr}$ and then, the cells were lysed subsequently. Titer of the phage SP-10 in the culture filtrate after $7.5 \mathrm{hr}$ was $2.0 \times 10^{10}$ P.F.U $/ \mathrm{ml}$. Bacillus subtilis JNo. 2 was transduced with the phage SP-10 as indicated above. The frequency of occurrence of ade $^{+}$transductants was not so different between multiplicity of infection 0.18 and 0.90 .

After transductants thus obtained were purified by single colony isolation, they were examined for growth rate in medium 4, phage sensitivity and lysogenicity. Strain TR-44 which satisfied these test was decided as the starting strain for derivating the mutants.

\section{Growth inhibition of Bacillus subtilis TR-44 \\ by various tryptophan analogues and its reversal by L-tryptophan}

Growth inhibition of Bacillus subtilis TR -44 by various tryptophan analogues and its reversion by L-tryptophan was tested as in Table II. 5-Methyltryptophan, the most commonly used analogue as well as 6-fluorotryptophan had little inhibitory effect on the growth, while L-tryptophan had little reversing effect on the inhibition by 4-methyltryptophan, 6-methyltryptophan, and tryptophanhydroxamate. Although 7-azatryptophan strongly inhibited the growth and the inhibition was well reversed by L-tryptophan, frequency of occurrence of spontaneous resistant mutants was very high. As a result, 5-fluorotryptophan was the best analogue among tested. The growth of Bacillus subtilis TR-44 was completely inhibited in the presence of $200 \mu \mathrm{g} / \mathrm{ml}$ of 5FT and almost completely recovered from the inhibition by the addition of $200 \mu \mathrm{g} / \mathrm{ml}$ of L-tryptophan (Table II). 5-Methoxytryptophan, 7-methyltryptophan, a-methyltryptophan, and $\mathrm{N}$-acetyltryptophan had no inhibitory effect. The inhibitory test of 5FT in liquid culture agreed with the result in the plate culture as shown in Table II (Fig. 2 (a)).

\section{Isolation of L-tryptophan producing $5 F T$ re- sistant strains}

NG treated cells of Bacillus subtilis TR-44 were spread onto medium 2 agar plates containing various concentrations of $5 \mathrm{FT}$ and incubated for 2 days at $37^{\circ} \mathrm{C}$. As shown in Table III, frequency of appearence of 5FT resistant colonies decreased at concentrations more than $400 \mu \mathrm{g} / \mathrm{ml}$ of $5 \mathrm{FT}$, and was not changed up to $5000 \mu \mathrm{g} / \mathrm{ml}$ of $5 \mathrm{FT}$. On the other hand, percentage of mutants producing more L-tryptophan than parental strain TR-44 (produced $50 \mu \mathrm{g} / \mathrm{ml}$ of L-tryptophan in medium 6) among 5FT resistant strains was about $10 \%$, 
TABle II. Growth Inhibition of Bacillus subtilis TR-44 By Various Analogues AND ITS REVERSAL BY L-TRYPTOPHAN

$0.1 \mathrm{ml}$ of overnight culture of Bacillus subtilis TR-44 in medium 1 was inoculated on medium 2 agar plates containing the indicated amount of analogues. Cultures incubated at $37^{\circ} \mathrm{C}$ were recorded as $(+++)$ very good growth, $(++)$ good growth, $(+)$ medium growth, $( \pm)$ poor growth, $(-)$ no growth. a, $8.4 \times$ $10^{5}$ cells $/ \mathrm{ml} ; \mathrm{b}, 8.4 \times 10^{4}$ cells $/ \mathrm{ml}$.

\begin{tabular}{|c|c|c|c|c|c|c|c|c|c|c|}
\hline \multicolumn{3}{|c|}{ Tryptophan $(\mu \mathrm{g} / \mathrm{ml})$} & \multicolumn{4}{|c|}{0} & \multicolumn{4}{|c|}{200} \\
\hline \multicolumn{3}{|c|}{ Cultivation time (hr) } & \multicolumn{2}{|l|}{24} & \multicolumn{2}{|c|}{48} & \multicolumn{2}{|c|}{24} & \multicolumn{2}{|l|}{48} \\
\hline \multicolumn{3}{|c|}{ Number of cells/ml } & a & $b$ & a & $b$ & a & $\mathrm{b}$ & a & $b$ \\
\hline \multirow{23}{*}{ 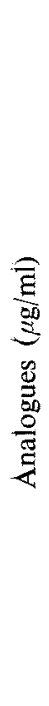 } & None & & +++ & + & $+t+$ & $+t$ & $+t+$ & + & $t+t$ & ++ \\
\hline & 4-Methyl- & 200 & - & - & + & \pm & ++ & + & +++ & + \\
\hline & 4-inetnyl- & $\{500$ & - & - & + & \pm & + & 1 & ++ & + \\
\hline & tryptophan & 1000 & - & - & - & - & - & - & - & - \\
\hline & 5-Methyl- & $\int 200$ & ++ & \pm & $++t$ & ++ & $++t$ & + & ++1 & ++ \\
\hline & tryptophan & 500 & ++ & - & $++t$ & + & +++ & + & $++t$ & ++ \\
\hline & & $\begin{array}{l}1000 \\
200\end{array}$ & + & - & + & $\overline{-}$ & $\begin{array}{l}+++ \\
++\end{array}$ & - & $\begin{array}{l}+++ \\
++\end{array}$ & - \\
\hline & 6-Methyl- & $\left\{\begin{array}{l}200 \\
500\end{array}\right.$ & $\equiv$ & - & $\begin{array}{l}+ \\
+\end{array}$ & + & $\begin{array}{l}++ \\
-\end{array}$ & 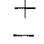 & $\begin{array}{c}++ \\
+\end{array}$ & + \\
\hline & tryptophan & $\begin{array}{r}500 \\
1000\end{array}$ & - & - & \pm & - & - & - & \pm & \pm \\
\hline & 5-Fluoro- & 200 & -- & - & - & - & +++ & + & $++t$ & + \\
\hline & $\begin{array}{l}\text {-Filuoro- } \\
\text { tryptophan }\end{array}$ & 500 & - & - & - & - & $+t+$ & + & $++t$ & + \\
\hline & & 1000 & - & - & - & - & ++ & + & ++ & + \\
\hline & 6-Fluoro- & $\int \begin{array}{l}200 \\
500\end{array}$ & + & \pm & ++ & + & + & + & +++ & + \\
\hline & tryptophan & $\left\{\begin{array}{r}500 \\
1000\end{array}\right.$ & + & \pm & + & $\begin{array}{l}+ \\
+\end{array}$ & $\begin{array}{l}+ \\
+\end{array}$ & $\begin{array}{l}+ \\
+\end{array}$ & $\begin{array}{c}+++ \\
++\end{array}$ & + \\
\hline & & 200 & - & - & - & - & $+t+$ & + & $+1+$ & $t^{\top}+$ \\
\hline & 7-Azatryptophan & 500 & - & - & - & - & $+t+$ & + & +++ & ++ \\
\hline & & 1000 & - & - & - & - & + & + & ++ & ++ \\
\hline & 5-Hydroxy- & 200 & - & - & + & \pm & $+t$ & + & +++ & + \\
\hline & $\begin{array}{l}\text { tryptophan } \\
\text { tryptoxy- }\end{array}$ & $\left\{\begin{array}{r}500 \\
50\end{array}\right.$ & - & - & \pm & - & + & \pm & ++ & + \\
\hline & пурторnan & 1000 & - & - & 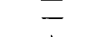 & - & \pm & $\overline{ \pm}$ & ++ & + \\
\hline & Tryptophan & $\left(\begin{array}{l}200 \\
500\end{array}\right.$ & - & 一 & \pm & - & $\rightarrow$ & - & \pm & \pm \\
\hline & hydroxamate & $\left\{\begin{array}{r}500 \\
1000\end{array}\right.$ & - & 一 & 一 & 一 & - & - & - & - \\
\hline & & $(1000$ & - & - & - & - & - & - & - & - \\
\hline
\end{tabular}

(a)

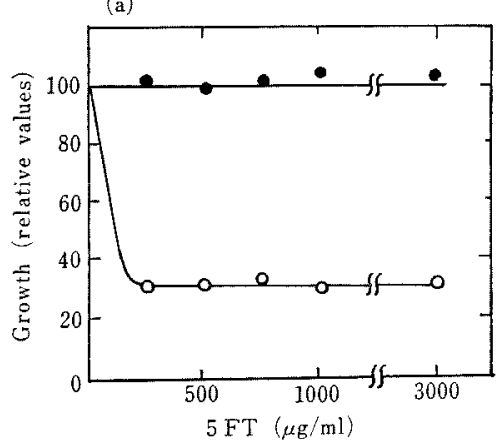

(b)

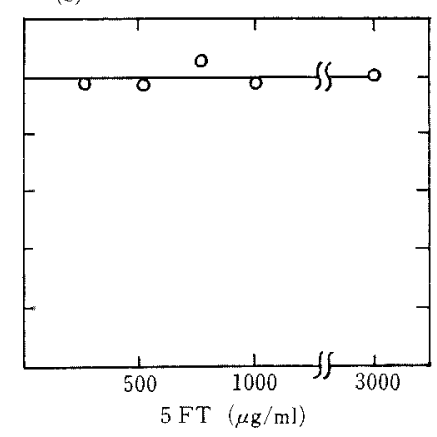

FIG. 2. Growth of Strain TR-44, (a) and FT-39, (b) in Medium 2 Containing 5FT and 5FT plus L-Tryptophan.

Overnight cultures of TR-44 and FT-39 in $5 \mathrm{ml}$ of medium 2 were harvested and washed with potassium phosphate buffer and resuspended in $5 \mathrm{ml}$ of medium 2 . A $0.1 \mathrm{ml}$ of the cell suspensions was added to series of $6 \mathrm{ml}$ of medium 2 containing various concentration $5 \mathrm{FT}$ and incubated for $24 \mathrm{hr}$ at $30^{\circ} \mathrm{C}$. The growth was determined by measuring optical density at $562 \mathrm{~m} \mu$ after dilution with water.

$0-0$, 5FT; - , 5FT plus L-tryptophan $(200 \mu \mathrm{g} / \mathrm{ml})$. 
Table III. Appearance of Tryptophan Producing 5FT Resistant Mutants from NG Treated Bacillus subtilis TR-44 AT Various Concentration of 5FT

NG treated cells of Bacillus subtilis TR-44 were spread onto medium 2 plates containing various concentration of $5 F T$ and incubated for 2 days at $37^{\circ} \mathrm{C}$. Appeared colonies were purified and cultured at $30^{\circ} \mathrm{C}$ for $72 \mathrm{hr}$ in $3 \mathrm{ml}$ of medium 4 and L-tryptophan produced were determined.

\begin{tabular}{|c|c|c|c|c|c|c|c|}
\hline $\begin{array}{c}\text { NG } \\
\text { conditions }\end{array}$ & $\begin{array}{l}\text { Viable } \\
\text { cells/ml }\end{array}$ & $\begin{array}{c}\text { Concentration } \\
\text { of } \\
5 F \mathrm{~T}(\mu \mathrm{g} / \mathrm{ml})\end{array}$ & $\begin{array}{l}\text { Number of } \\
\text { cells } \\
\text { treated }\end{array}$ & $\begin{array}{l}\text { Number of } \\
\text { resistant } \\
\text { colonies }\end{array}$ & $\begin{array}{c}\text { Frequency } \\
\text { of } \\
\text { resistance }\end{array}$ & $\begin{array}{l}\text { Number of } \\
\text { tested } \\
\text { colonies }\end{array}$ & $\begin{array}{l}\text { Number of } \\
\text { tryptophan } \\
\text { producer }\end{array}$ \\
\hline \multirow{2}{*}{$\begin{array}{l}750(\mu \mathrm{g} / \mathrm{ml}) \\
0^{\circ} \mathrm{C} \\
30 \mathrm{~min}\end{array}$} & $2.9 \times 10^{8}$ & 200 & $\begin{array}{l}1.0 \\
1.0 \\
1.0\end{array}$ & $\begin{array}{r}2.1 \times 10^{2} \\
2\end{array}$ & $\begin{array}{l}2.1 \times 10^{-3} \\
2.0 \times 10^{-4}\end{array}$ & 180 & 24 \\
\hline & $1.0 \times 10^{6}$ & 300 & $\begin{array}{l}1.0 \times 10^{5} \\
1.0 \times 10^{4}\end{array}$ & $\begin{array}{c}1.2 \times 10^{2} \\
1\end{array}$ & $\begin{array}{l}1.2 \times 10^{-3} \\
1.0 \times 10^{-4}\end{array}$ & 144 & 19 \\
\hline \multirow{2}{*}{$\begin{array}{l}500(\mu \mathrm{g} / \mathrm{ml}) \\
0^{\circ} \mathrm{C} \\
30 \mathrm{~min}\end{array}$} & $2.5 \times 10^{9}$ & 400 & $\begin{array}{l}7.5 \times 10^{6} \\
7.5 \times 10^{5}\end{array}$ & $\begin{array}{c}4.6 \times 10^{2} \\
10\end{array}$ & $\begin{array}{l}6.1 \times 10^{-5} \\
1.3 \times 10^{-5}\end{array}$ & 220 & 12 \\
\hline & $7.5 \times 10^{7}$ & 600 & $\begin{array}{l}7.5 \times 10^{6} \\
7.5 \times 10^{5}\end{array}$ & $\begin{array}{c}4.0 \times 10^{2} \\
8\end{array}$ & $\begin{array}{l}5.3 \times 10^{-5} \\
1.1 \times 10^{-5}\end{array}$ & 110 & 11 \\
\hline $\begin{array}{l}500(\mu \mathrm{g} / \mathrm{ml}) \\
0^{\circ} \mathrm{C} \\
30 \mathrm{~min}\end{array}$ & $\begin{array}{l}1.6 \times 10^{9} \\
8.0 \times 10^{6}\end{array}$ & $\begin{array}{l}1500 \\
2000 \\
3000\end{array}$ & $\begin{array}{l}8.0 \times 10^{5} \\
8.0 \times 10^{5} \\
8.0 \times 10^{5}\end{array}$ & $\begin{array}{c}4.1 \times 10^{2} \\
2.9 \times 10^{2} \\
70\end{array}$ & $\begin{array}{l}5.1 \times 10^{-4} \\
3.6 \times 10^{-4} \\
8.7 \times 10^{-5}\end{array}$ & $\begin{array}{l}110 \\
110 \\
110\end{array}$ & $\begin{array}{l}16 \\
18 \\
10\end{array}$ \\
\hline $\begin{array}{l}750(\mu \mathrm{g} / \mathrm{ml}) \\
0^{\circ} \mathrm{C} \\
30 \mathrm{~min}\end{array}$ & $\begin{array}{c}2.9 \times 10^{8} \\
\downarrow \\
1.0 \\
1\end{array}$ & 5000 & $1.0 \times 10^{5}$ & 47 & $4.7 \times 10^{-4}$ & 50 & 10 \\
\hline
\end{tabular}

when selected on $300 \mu \mathrm{g} / \mathrm{ml}$ of $5 \mathrm{FT}$ plates, while about $5 \%$ when selected on plates containing more than $400 \mu \mathrm{g} / \mathrm{ml}$ of $5 \mathrm{FT}$. The best strain FT-39 which excreted $0.9 \mathrm{~g} /$ liter of L-tryptophan in medium 4 was isolated from the plates containing $1500 \mu \mathrm{g} / \mathrm{ml}$ of 5FT. As shown in Fig. 2(b), the growth of FT-39 was completely free from the inhibition by $5 \mathrm{FT}$ at the concentration up to $3,000 \mu \mathrm{g} / \mathrm{ml}$.

Culture conditions for L-tryptophan production

Although medium 4 had been used as the screening medium, a preliminary experiment indicates better tryptophan production with medium 5 than medium 4 . Therefore, effects of concentration of components of the cultural medium on L-tryptophan production were examined using medium 5 as the basal medium.

The results with strain FT-39 are shown in Fig. 3. As $0.4 \%$ of the amino acid mixture was better than the concentration of the amino acid mixture in the basal medium, this concentration of the amino acid mixture was used for the L-tryptophan production.

The reproducible maximum amount of

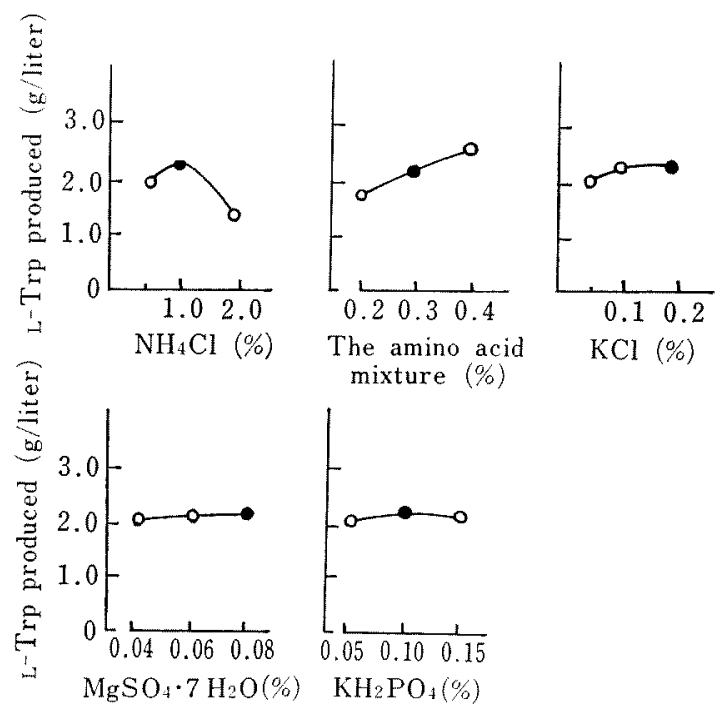

Fro. 3. Effect of Concentration of Components in Culture Medium on L-Tryptophan Production by Strain FT-39.

Strain FT-39 was cultured in media as indicated in the figures for $72 \mathrm{hr}$ at $30^{\circ} \mathrm{C}$ in flasks on a shaker. Closed circles show the amount of L-tryptophan accumulated in the basal medium (medium 5 ).

L-tryptophan produced was $2.0 \mathrm{~g} /$ liter in medium 6. 
Anthranilate synthetase in FT-39

As shown in Table IV, anthranilate synthetase activity in FT-39 was elevated to 280 -fold than that in TR-44, while the activity in a tryptophan auxotroph, TT 4 , derived from TR-44 was derepressed 200-fold under a limiting condition as reported with various strains of Bacillus subtilis. ${ }^{11)}$ Therefore, anthranilate synthetase seems to have been genetically derepressed in FT-39. On the other hand,

Table IV. Anthranilate Synthetase Levels in Tryptophan Producing 5FT Resistant Mutant

TR-44 and FT-39 were grown for $24 \mathrm{hr}$ in medium 6 without tryptophan, and TT -4 were grown with a limited amount of tryptophan $(25 \mu \mathrm{g} / \mathrm{ml})$. Extracts obtained by sonic oscillation were assayed as described in the text.

\begin{tabular}{lccc}
\hline Strain & $\begin{array}{c}\text { Addition } \\
\text { of } \\
\text { tryptophan } \\
(\mu \mathrm{g} / \mathrm{ml})\end{array}$ & Growth & $\begin{array}{c}\text { Specific } \\
\text { activity }^{a}\end{array}$ \\
\hline TR-44 & 0 & 0.69 & 0.14 \\
TT-4 & 25 & 0.42 & 29.00 \\
FT-39 & 0 & 0.61 & 39.70 \\
\hline
\end{tabular}

a) Milimicromoles anthranilate formed for $30 \mathrm{~min}$ per mg protein.

feedback inhibition by L-tryptophan of anthranilate synthetase in FT-39 was almost the same as in TT-4 (Fig. 4), 50\% inhibition of anthranilate synthetase activity in FT-39 was shown at $7.5 \times 10^{-6} \mathrm{M}$ of L-tryptophan.

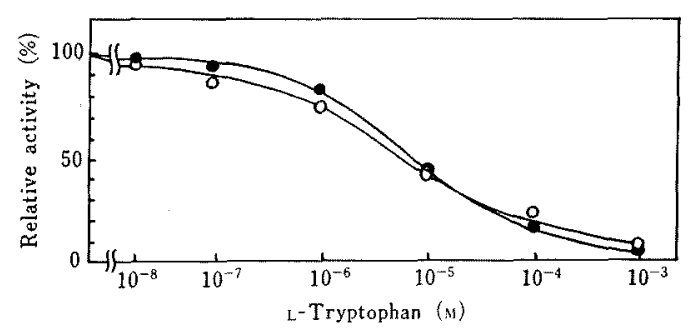

FIG. 4. Effect of L-Tryptophan on Anthranilate Synthetase from Mutant and the Tryptophan Auxotroph from Parental Strain.

Activities were measured under the standard assay conditions and L-tryptophan was added as indicated.

- - TT-4; O-O, FT-39; L-tryptophan producer.

Derivation of mutants resistant to higher concentration of $5 F T$ from strain $F T-39$

Although FT-39 was resistant to $3,000 \mu \mathrm{g} /$ $\mathrm{ml}$ of $5 \mathrm{FT}$ in Fig. 2(b), the growth was still inhibited at a concentration more than $4000 \mu \mathrm{g} /$ $\mathrm{ml}$ of 5FT (Table V). Thus, about a hundred mutants resistant to $7000 \mu \mathrm{g} / \mathrm{ml}$ of 5FT were derived from FT-39 by NG treatment. Distribution of these mutants with respect to the L-tryptophan production is shown in Fig. 5. Among tested mutants, about thirty strains produced more L-tryptophan than did the parental strain. L-Tryptophan productivities in medium 6 of the best three strains, FF-25, FF-65, FF-74 were 4.0, 3.4, $3.3 \mathrm{~g} /$ liter, respectively. Time course of growth, $\mathrm{pH}$, and L-tryptophan production in strain FF-25

Table V. Growth InHIBItion of Bacillus subtilis FT-39 by Various Concentration of 5FT

A $0.1 \mathrm{ml}$ of overnight culture of Bacillus subtilis FT-39 in medium 1 was inoculated on medium 2 agar plates containing the indicated amount of $5 \mathrm{FT}$. Cultures incubated at $37^{\circ} \mathrm{C}$ were recorded as $(+++)$ very good growth, $(++)$ good growth $(+)$, medium growth, $( \pm)$ poor growth, $(-)$ no growth. a, $1.9 \times$ $10^{6}$ cells $/ \mathrm{ml} ; \mathrm{b}, 1.9 \times 10^{5}$ cells $/ \mathrm{ml}$.

\begin{tabular}{|c|c|c|c|c|c|c|c|c|c|}
\hline \multirow{2}{*}{\multicolumn{2}{|c|}{$\begin{array}{l}\text { Tryptophan }(\mu \mathrm{g} / \mathrm{ml}) \\
\text { Cultivation time }(\mathrm{hr})\end{array}$}} & \multicolumn{4}{|c|}{0} & \multicolumn{4}{|c|}{200} \\
\hline & & \multicolumn{2}{|c|}{24} & \multicolumn{2}{|c|}{48} & \multicolumn{2}{|c|}{24} & \multicolumn{2}{|c|}{48} \\
\hline \multicolumn{2}{|c|}{ Inoculated cells/ml } & $\mathrm{a}$ & $b$ & a & $b$ & $\mathrm{a}$ & $b$ & $a$ & $\mathrm{~b}$ \\
\hline \multirow{6}{*}{ 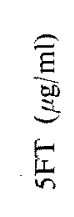 } & 0 & $+t$ & \pm & $+t+$ & ++ & ++ & + & $++t$ & ++ \\
\hline & 1500 & \pm & \pm & ++ & + & \pm & \pm & $t+$ & + \\
\hline & 2000 & - & - & + & \pm & \pm & - & + & \pm \\
\hline & 3000 & - & - & \pm & - & - & - & \pm & - \\
\hline & 4000 & - & - & - & - & - & - & - & - \\
\hline & 5000 & - & - & - & - & - & - & - & - \\
\hline
\end{tabular}




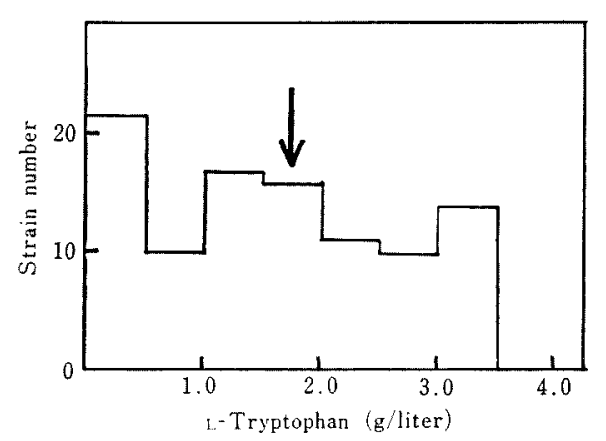

FIG. 5. Distribution of 5FT Resistant Mutants Derived from Strain FT-39 with Respect to Their L-Tryptophan Production.

Mutants resistant to $7000(\mu \mathrm{g} / \mathrm{ml})$ of 5FT were isolated from NG treated FT-39 and cultured in $3 \mathrm{ml}$ of medium 6 .

L-Tryptophan was determined after culturing for $72 \mathrm{hr}$ at $30^{\circ} \mathrm{C}$ on a shaker. The arrow shows the amount of L-tryptophan produced by the parental strain, FT-39.

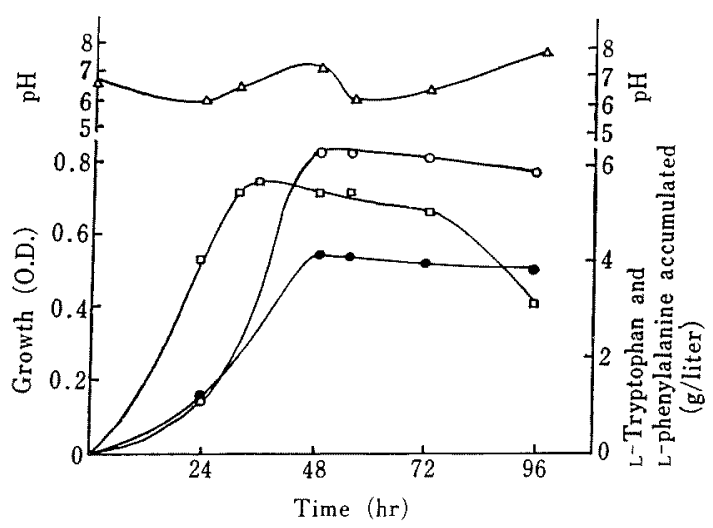

FIG. 6. Time Course of Growth, pH, L-Tryptophan and L-Phenylalanine Accumulation of Strain FF-25.

A loopful of cells grown on medium 1 plate for $24 \mathrm{hr}$ at $30^{\circ} \mathrm{C}$ were inoculated into $20 \mathrm{ml}$ of medium 6 distributed in $500 \mathrm{ml}$ flasks.

$\triangle-\triangle, \mathrm{pH} ; \square-\square$, growth; - - L-tryptophan accumulation; $\mathrm{O}-\mathrm{O}$, L-phenylalanine accumulation.

was investigated using medium 6 as shown in Fig. 6. The maximum level of L-tryptophan accumulation was $4.0 \mathrm{~g} /$ liter after $48 \mathrm{hr}$. More remarkable was the fact that large amount of L-phenylalanine as well as Ltryptophan was produced in strain FF-25 which was scarecely done in strain FT-39. As specific activity of anthranilate synthetase as well as level of the feedback inhibition in strain FF-25 was almost identical with those in strain FT-39, it is likely that this strain may be altered in some properties involved in the common pathway of the aromatic amino acid biosynthesis.

\section{Derivation of auxotrophs from $5 F T$ resistant mutants}

Various auxotrophs were derived from strain FT-39 and FF-25, 5FT resistant mutants. Among them, producers better than the parental strains were selected and tested for the optimum concentrations of the supplements to the culture media.

Tables VI and VII shows the result with phenylalanine, arginine, leucine, lysine, and purine auxotrophs and a leucine bradytroph which produced more L-tryptophan than did the parental strains. A strain FFL-90, leucine bradytroph, was the best strain which produced $6.15 \mathrm{~g} /$ liter of L-tryptophan in medium 6 containing of $300 \mu \mathrm{g} / \mathrm{ml}$ of L-leucine. Although histidine auxotrophs produced in a histidine supplemented medium, more than did the parental strains in the medium without supplement, addition of L-histidine $(500 \mu \mathrm{g} /$ $\mathrm{ml})$ markedly increased the accumulation of L-tryptophan in strain FT-39 and FF-25, parental strains. Thus, the accumulation of L-tryptophan increased from $2.01 \mathrm{~g} /$ liter to $3.44 \mathrm{~g} /$ liter in FT-39, and from $4.00 \mathrm{~g} /$ liter to $4.44 \mathrm{~g} /$ liter in $\mathrm{FF}-25$ by the addition of $500 \mu \mathrm{g} / \mathrm{ml}$ of L-histidine. Therefore, increase of L-tryptophan in histidine auxotrophs is not due to their auxotrophy but the histidine addition. This promotive effect of L-histidine has been reported by Kane and Jensen. ${ }^{17)}$

\section{DISCUSSION}

It has been known that L-tryptophan inhibits anthranilate synthetase and represses enzymes of the tryptophan specific biosynthetic pathway in Bacillus subtilis. Further, chorismic acid and prephenic acid, common precursors of aromatic amino acids, inhibit 3-deoxy-D-arabinoheptulosonic acid 7-phos- 
Table VI. L-Tryptophan Production of Various Auxotrophs from Strain FT-39

Cultivation was carried out using $20 \mathrm{ml}$ of medium 6 distributed in $500 \mathrm{ml}$ flasks supplemented with the described concentrations of supplements for $48 \mathrm{hr}$ at $30^{\circ} \mathrm{C}$. Parental strain FT-39 produced $2.06 \mathrm{~g} /$ liter of L-tryptophan.

\begin{tabular}{|c|c|c|c|c|c|}
\hline Strain & Auxotrophy & $\begin{array}{l}\text { Supplements } \\
(\mu \mathrm{g} / \mathrm{mnl})\end{array}$ & & O.D. & $\underset{(\mathrm{g} / \text { liter })}{\text { L-Tryptophan }}$ \\
\hline \multirow[t]{2}{*}{ FP-13 } & Phe ${ }^{-}$ & L-Phenylalanine & 50 & 0.72 & 2.56 \\
\hline & & & 200 & 0.53 & 2.93 \\
\hline \multirow[t]{2}{*}{ FA-32 } & $\mathrm{Arg}^{-}$ & L-Arginine & 200 & 0.44 & 2.59 \\
\hline & & & 400 & 0.51 & 2.87 \\
\hline \multirow[t]{2}{*}{ FA-39 } & $\mathrm{Arg}^{-}$ & L-Arginine & 200 & 0.53 & 2.57 \\
\hline & & & 400 & 0.69 & 2.44 \\
\hline \multirow[t]{2}{*}{$F L-97$} & Lys ${ }^{-}$ & L-Lysine & 400 & 0.66 & 2.54 \\
\hline & & & 500 & 0.65 & 2.09 \\
\hline
\end{tabular}

Table VII. L-Tryptophan Production of Various Auxotrophs from Strain FF-25

Cultivation was carried out using $20 \mathrm{ml}$ of medium 6 distributed in $500 \mathrm{ml}$ flasks supplemented with the described concentration of supplementes for $48 \mathrm{hr}$ at $30^{\circ} \mathrm{C}$. Parental strain FF-25 produced $4,13 \mathrm{~g} /$ liter of L-tryptophan.

$\mathrm{X}^{-}, \mathrm{X}$ auxotroph; $\mathrm{X}^{ \pm}, \mathrm{X}$ bradytroph.

\begin{tabular}{|c|c|c|c|c|c|}
\hline Strain & Auxotrophy & $\begin{array}{r}\text { Supplem } \\
(\mu \mathrm{g} / \mathrm{m}\end{array}$ & & O.D. & $\begin{array}{l}\text { L-Tryptophan } \\
\text { (g/liter) }\end{array}$ \\
\hline \multirow[t]{2}{*}{ FFA-3 } & $\mathrm{Arg}^{-}$ & L-Arginine & 300 & 0.52 & 2.45 \\
\hline & & & 500 & 0.58 & 5.20 \\
\hline \multirow[t]{2}{*}{ FFA-39 } & $\mathrm{Arg}^{-}$ & L-Arginine & 300 & 0.43 & 5.23 \\
\hline & & & 500 & 0.44 & 4.00 \\
\hline \multirow[t]{2}{*}{ FFL-5 } & $\mathrm{Leu}^{-}$ & L-Leucine & 200 & 0.70 & 5.30 \\
\hline & & & 300 & 0.66 & 5.25 \\
\hline \multirow[t]{2}{*}{ FFL-90 } & Leu \pm & L-Leucine & 200 & 0.60 & 5.66 \\
\hline & & & 300 & 0.49 & 6.15 \\
\hline \multirow[t]{2}{*}{ FFU-6 } & Pur $^{-}$ & Adenine & 200 & 0.59 & 4.56 \\
\hline & & & 300 & 0.60 & 4.75 \\
\hline \multirow[t]{2}{*}{ FFU-34 } & Pur ${ }^{-}$ & Adenine & 200 & 0.37 & 5.00 \\
\hline & & & 300 & 0.59 & 4.49 \\
\hline \multirow[t]{2}{*}{ FFU-80 } & Pur ${ }^{-}$ & Adenine & 200 & 0.52 & 4.28 \\
\hline & & & 300 & 0.43 & 5.41 \\
\hline
\end{tabular}

phate synthetase (DAHP synthetase) and shikimate kinase in the common pathway of the aromatic amino acid biosynthesis. In this type of regulation which has been known as the sequential feedback inhibition, it is expected that a release of the feedback regulation in the tryptophan specific pathway may easily give an accumulation of tryptophan. In fact, strain FT-39, which was resistant to 5FT and genetically derepressed in the tryptophan specific pathway, overproduced $2 \mathrm{~g} /$ liter of L-tryptophan. In strain FF-25, a mutant resistant to higher concentration of $5 \mathrm{FT}$, in which the feedback inhibition and derepression of anthranilate synthetase were almost identical with those in FT-39, $4.0 \mathrm{~g} /$ liter of L-tryptophan and $6.0 \mathrm{~g} /$ liter of L-phenylalanine were simultaneously accumulated. Therefore, this strain would have been altered in the regulation of the common pathway of the aromatic amino acid biosynthesis.

In Bacillus subtilis, the first enzyme of the common pathway, DAHP synthetase, which is inhibited by chorismate and prephenate is repressed by L-tyrosine and more strongly by L-tyrosine plus L-phenylalanine, while the 
first enzyme of the L-phenylalanine specific pathway, prephenate dehydratase is inhibited by L-phenylalanine (Fig. 1). Therefore, desensitization of the latter enzyme to the feedback inhibition would be essential for the overproduction of L-phenylalanine. In fact, $\beta$-thienylalanine resistant mutant of Bacillus subtilis WB-740, whose prephenate dehydratase is completely feedback resistant has been reported to excrete L-phenylalanine. ${ }^{18)}$ Thus, it is possible that strain $F F-25$ producing L-phenylalanine may have desensitized prephenate dehydratase, similar to strain WB740. Moreover, as suggested by Nester et al., ${ }^{11}$ an excess production of L-phenylalanine in addition to L-tryptophan may cause a limitation of L-tyrosine, which, in turn, may derepress key enzymes of the common pathway. Therefore, it is likely that higher production of L-tryptophan in FF-25 than FT-39 may come from phenotypic derepression of key enzymes of the common pathway. Although desensitization of DAHP synthetase to the feedback inhibition by chorismate may increase the L-tryptophan production, it is not clear whether this alteration simultaneously causes an overproduction of L-phenylalanine or not.

Furthermore, the yield of L-tryptophan was increased in the following nutritional mutants derived from strain FF-25, that is, $5.23 \mathrm{~g} /$ liter in strain FFA-39, an arginine auxotroph; $5.30 \mathrm{~g} /$ liter in strain FFL-5, a leucine auxotroph; $6.15 \mathrm{~g} /$ liter in strain FFL-90, a leucine bradytroph; and $5.41 \mathrm{~g} /$ liter in strain FFU-80, a purine auxotroph.

The enhancement of L-tryptophan production by leucine auxotroph and bradytroph is very interesting if compared with the fact that leucine activates prephenate dehydratase and reverses the inhibition by tryptophan. ${ }^{19}$ ) All the tryptophan producing mutants obtained in the present study have been not altered with respect to the feedback inhibition of anthranilate synthetase, although desensitization to this feedback inhibition may be very important for the better production of $\mathrm{L}$ tryptophan.

Acknowledgements. The authors are indebted to Director Dr. T. Tsunoda and Assistant Director Dr. M. Takahashi of their laboratories for the encouragement during the course of this work. They also wish to thank Miss K. Furuya for her skillful technical assistance.

\section{REFERENCES}

1) B. Marlin and $\mathbf{J}$. Westhead, I. Biochem. Microbiol. Technol. Eng., 1, 49 (1959).

2) Chugai Seiyaku Co., French Patent 1437993 (1966).

3) G. Terui and T. Enatsu, Amino Acid and Nucleic Acid, 3, 71 (1961).

4) A. Donald, Japanese Patent 2384 (1960).

5) P. G. Lim and R. I. Mateles, Science, 140, 338 (1963).

6) I. Shiio, H. Sato and M. Nakagawa, Agr. Biol. Chem., 36, 2315 (1972).

7) R. Aoki, H. Momose, Y. Kondo, N. Muramatsu and Y. Tsuchiya, J. Gen. Appl. Microbiol., 9, 387 (1963).

8) R. A. Jensen and E. W. Nester, J. Mol. Biol., 12, 468 (1965).

9) R. A. Jensen and E. W. Nester, J. Biol. Chem., 241, 3373 (1966).

10) E. W. Nester and R. A. Jensen, J. Bacteriol., 91, 1594 (1966).

11) E. W. Nester, R. A. Jensen and D. S. Nasser, ibid., 97, 83 (1969).

12) D.S. Nasser, G. Henderson and E. W. Nester, ibid., 98, 44 (1969).

13) J. F. Kane and R. A. Jensen, Biochem Biophys. Res. Commun., 38, 1161 (1970).

14) F. Gibson, Biochem. J., 90, 256 (1964).

15) I. Shiio and R. Miyajima, J. Biochem., 72, 1447 (1972).

16) O. H. Lowry, N. J. Rosebrough, A. L. Farr and R. J. Randal, J. Biol. Chem., 193, 265 (1951).

17) J. F. Kane and R. A. Jensen, ibid, 245, 2384 (1970).

18) J. H. Coats and E.W. Nester, ibid., 242, 4948 (1967).

19) J. L. Rebello and R. A. Jensen, ibid., 245, 3378 (1970). 